\title{
Dynamics and Dilemmas of Women Leading Women
}

\author{
Jean M. Bartunek \\ Department of Organization Studies \\ Boston College \\ Chestnut Hill, Massachusetts \\ 02467-3808, bartunek@bc.edu \\ Kate Walsh \\ School of Hotel Administration \\ Cornell University \\ Ithaca, New York 14853-2801, kmw33@cornell.edu \\ Catherine A. Lacey \\ Spencer Foundation \\ 875 N. Michigan Avenue, Suite 3930 \\ Chicago, Illinois 60611, \\ clacey@spencer.org
}

\begin{abstract}
"While empowerment is an issue of our time, it has been particularly important in the feminist movement. This paper reports a longitudinal study of leadership successions in six-year evolution of a group designed to empower women. It particularly focuses on the polar tension between initiation and support on the part of the group leader. Over time this tension becomes a difficult challenge. In the end we learn that the very objective of an empowerment group tends to call forth ambivalence about leadership. Empowerment itself seems to require a simultaneous enactment of both sides of the polarity. When leaders attempt to reduce the tensions around the polarity, they may experience the unintended consequence of reducing the capacity of the group to act. This paper not only furthers our understanding of the dynamics of empowerment in feminist efforts but it calls our attention to the paradoxical issues of leadership and empowerment in all groups."

-Robert E. Quinn
\end{abstract}




\begin{abstract}
Through examination of transcripts of the first five leadership succession discussions that occurred in a work group designed to empower teachers we explored dynamics and dilemmas associated with women leading a women's group based on feminist principles. We addressed three research questions: How is leadership, as reflected in leadership succession processes, experienced in such a group? What dynamics are associated with leadership succession in this type of group? What are outcomes of the process for members? Results indicated that the experience of leadership shifted considerably during the first six years of the group, with reflective images of leadership moving from the mythical to the pragmatic, from the powerful to the less powerful. Dynamics evolved in ways that were partially consistent and partially inconsistent with organizational life-cycle literature. The group experienced ambivalence and tension surrounding the type of authority given to designated leaders. Members dealt with discomfort by shifting the focus of the group coordinator's attention to external relations and by rotating internal leadership responsibilities. This approach resolved tensions associated with authority and increased members' senses of their own power, even as it decreased the range of initiative-taking that was implicitly allowable within the group. This analysis of leadership succession in a women's group with an empowerment agenda offers a salient case for the study of dilemmas likely to be present in many change efforts. Its results suggest that attempting to resolve contradiction and tensions is less helpful than acknowledging them and working within them.
\end{abstract}

KEYWORDS: empowerment; work groups; leadership; women's leadership; women's groups 
From traditional trait and behavioral theories to newer ideas of charismatic (House 1977) and transformational leadership (Burns 1978, Tichy and Ulrich 1984, Bass 1985), leadership research has focused on effective ways a leader may direct a group or organization in stable times, and, more recently, through dramatic organizational change. Many approaches in past years focused more or less explicitly on task-directed initiatives leaders take. In contrast, many recent approaches concentrate on how leaders empower others, encouraging and developing capacities to take initiative (e.g., Denmark 1994). For example, Conger (1989) described leadership as the "art of empowering others," and Sims and Lorenzi's (1992) model of superleadership suggests ways leaders may create self-leadership and self-direction in followers rather than lead and direct the followers themselves. Papers that discuss coaching and facilitation of work teams offer equivalent foci (Berg 1990, Hackman and Walton 1986, Yukl 1998).

The approach that research on empowering leadership advocates for managers has some similarities to, and differences from, the kind of nurturing leadership role often (perhaps stereotypically) assumed as appropriate for women (e.g., Correa et al. 1988, Kram and Hampton 1998), a role in which women leaders support group members and facilitate their participation in a setting. It is similar in that it focuses on supporting others' contributions. It is different in that it involves the leader taking active initiative, albeit towards fostering group members' capacities through directing group processes as opposed to specific task goals.

Despite some similarities between the type of leadership often assumed appropriate for women and the types of leadership seen as empowering, empirical research has not often directly explored relationships between women's leadership styles and the empowerment of members or subordinates. A women's work group designed to empower its members, especially such a group based on feminist principles that espouse an egalitarian ideology (e.g., Riger 1994), offers a natural site for empirical investigation of this relationship.

We will undertake such an investigation here, but not without considering the problems raised by the gendered notions brought to bear in evaluating leaders. Nieva and Gutek (1981), Kram and Hampton (1998), Vroom and Jago (1995), and others show that people often assess the leadership styles of men and women differently, valuing initiating behavior more highly in men and concern for others more highly in women. Moreover, research addressing leadership has often indicated that women who lead in nurturing and facilitative ways are likely to be accepted and rated highly as leaders by both men and women group members, while women who take initiative (apparently regardless of the type of initiative they take) are less likely to be rated in this way (Eagly et al. 1995, Jago and Vroom 1982, Vroom and Jago 1995). Although this is not always true, it does seem to be the case over a variety of circumstances, including those in which the path-goal model would suggest that supportive leadership is not appropriate (cf. Jago and Vroom 1982, Klenke 1996, Yukl 1998, ch. 11).

Thus, women leading groups of women, especially in groups that aim to empower their members and whose designs are based on feminist principles, are likely to experience a dilemma. How much initiative can and should they take, even if their initiative is aimed at fostering members' empowerment? This is similar to the dilemma experienced by supervisors of self-managed work teams: how does one lead others who are supposed to lead themselves (Manz and Sims 1984, Stewart and Manz 1995)? Not only because of their role but also because of their gender, women leaders are likely to experience this dilemma in a heightened form.

A dilemma like this is particularly salient during leadership succession processes, occasions set aside to determine who will replace leaders whose terms have been completed. The discussions that emerge around leadership succession sometimes surface praise of a current 
leader and leadership style (Gordon and Rosen 1981) and sometimes surface discontent with the present style (Gephart 1978, Heller 1989). Thus, leadership successions are particularly appropriate occasions for examining how leadership styles are experienced by members of a setting, and the dynamics and dilemmas associated with particular approaches to leadership. They provide occasions for members to reflect in depth about how they experience leadership, to discuss and respond to the type of leadership they have been experiencing, to discern what they want from leaders and themselves, and to choose the kind of leadership style they desire.

In this paper we explore images and dilemmas associated with leadership, along with relevant outcomes of leadership, in a women's work group based on feminist principles and aimed at empowering its members and others. We explore these elements as they were manifested in the first five leadership succession discussions in a group of teachers called the Network Faculty Development Committee (NFDC). The group was designed by its founders, Catherine Lacey and Diane Wood, to empower NFDC members and the more than 1,000 (mostly women) teachers in the Network of schools in which they worked. The leadership succession processes that occurred annually in this group, from its second year on, provided opportunities for the group to explore the principles and values the group wanted its leadership to embody.

We address three research questions that we introduce here and return to later after describing the conceptual foundations for our study. How is leadership, as reflected in leadership succession processes, experienced in a women's work group based on feminist principles? What dynamics are associated with leadership succession in this type of group? Finally, what are the implications of the leadership succession process for group members' sense of their own empowerment? This combination of questions has the potential to surface in-depth empirical understanding of dynamics and dilemmas associated with women's leadership in groups based on feminist principles that have empowerment agendas.

Our exploration regarding these questions is informed by several literature streams, including leadership and women's work groups, paradox and ambivalence associated with leadership in groups, and early life cycles of organizations. We summarize pertinent aspects of these literatures below.

\section{Literature Review and Conceptual Approach}

\section{Leadership and Women's Work Groups}

Women's work groups (particularly those based on feminist principles) have characteristics that distinguish them from men's groups or mixed gender groups. For example, Valentine's (1995) examination of the all women faculty of a nursing school found a focus on relationships that would provide support and camaraderie to group members. These findings are consistent with Gilligan's (1982) research and echoed by Miller and associates at the Stone Center for Research (Fletcher 1999, Miller 1976, Jordan 1997, Jordan et al. 1991), who found that women tend to see "a world that coheres through human connection rather than through systems of rules," and have the capacity individually to grow through these connections. Loden (1985) studied over 200 women in different types of businesses and concluded that women see a strong connection between maintaining positive relationships and releasing individual power. Loden's results were echoed by Hegelsen (1990) in her study of four women executives and by Eagly and Johnson (1990) in their metaanalysis of gender differences in leadership style. Both Loden and Hegelsen found that women tend to cooperate instead of compete with each other in 
work groups. As a way for group members to provide help and encouragement to each other, women also tend to seek input from multiple group members and are particularly likely to facilitate interactions and to lead in a democratic style (Eagly et al. 1992).

This emphasis on maintaining relationships influences women's approaches to group structure. Gilligan (1982) and Neuse (1978) both found that women tend to prefer more egalitarian, flat organizational structures to formal hierarchy; this is particularly true of feminist organizations (Riger 1994). Such structures better support environments that are more intimate and participative. Women also prefer a consensus-driven, teamlike decision-making style (Muller and Cocotas 1988, Rosener 1990, Valentine 1995). Loden (1985) contends that this emphasis on consensus encourages the group to focus its energy on reaching decisions that are acceptable to all members.

This literature suggests a reason why women leaders of groups designed on feminist principles are likely to face a dilemma regarding taking initiative. Members of such groups appear to expect strongly collegial, egalitarian environments (Riger 1994), and may view initiative-taking that appears to separate leaders from other group members as inappropriate.

\section{Leadership, Power, and Paradox in Work Groups}

Smith and Berg (1987) suggest that authority is one of the most paradoxical and contradictory aspects of group life. A group with a leader in charge implies that a hierarchical structure exists. Such a structure runs counter to notions of an egalitarian group, where all members have equal voice. Yet Smith and Berg contend that authority and empowerment are expressly linked, and that by empowering others, one gains more power. They suggest that groups often become locked in a paradox related to authority. Members become reluctant to take power because it implies "taking it away" from others. But, avoiding assuming power and exercising authority can make the individual, and ultimately the group, feel powerless and, perhaps, be powerless at critical moments.

Smith and Berg (1987) suggest that groups can escape this bind and increase their total power when one member takes power and uses it to create conditions that empower others. In describing roles for leaders of self-managing groups, Manz and Sims (1980) and Manz (1990) offer similar suggestions. But, Smith and Berg (1987) note that attempting to create conditions to empower others sometimes results in others becoming more dependent on the leader. For example, a group leader may try to help members take responsibility for decision making, perhaps by targeting areas where decisions need to be made and outlining a process for choosing the best alternative. The very process of setting the context and showing members how to take more responsibility can result in members allowing the leader to make the actual decisions. How does a leader truly help group members take responsibility for the group rather than tacitly set parameters of acceptable behavior or provide merely the illusion of empowerment while reproducing subtle forms of control and powerlessness (Manz 1990)?

Due to contradictory pulls of leadership in such situations, both leaders and members of women's empowering groups may feel especially ambivalent about their roles. Leaders may enjoy initiating group processes in ways that foster empowerment. But they may also experience guilt or self-doubt as their efforts seem to contradict the facilitative behavior they assume appropriate for women and/ or for groups based on feminist principles, where power is equally shared among all group members. Other group members may be both grateful to and resentful of their leaders 
for taking initiative and power, for equivalent reasons. This paradox is made more salient by lifecycle literature that suggests that appropriate leadership styles depend on a group's life stage.

\section{Literature on Early Life-Cycle Stages}

Most research on leadership has not paid particular attention to the group or organization's stage in its life cycle (for an exception see Hersey and Blanchard 1988). However, there is reason to expect that life-cycle stage, especially early in a group or organization, will affect leadership and individual initiative. In a comprehensive summary of research on organization life cycles, Quinn and Cameron (1983) propose that, at least in their first few years, newly forming groups and organizations go through fairly consistent transitions. Riger (1994) suggests that these transitions are as true of feminist organizations as any other type of organization. Initially the founder is the center of organizational attention and authority. As the organization grows, this central authority tends to result in a lack of coordination and cohesion (Cameron and Whetten 1983). In response, a strong sense of collectivity develops among members that is manifested in several informal communication mechanisms. While energy at this stage is typically high, the group or organization may be somewhat disorganized. Over time, especially if the organization's work is expanding, these informal communication structures may no longer adequately function, and members may burn out. Thus, pressures towards greater formalization develop; members are likely to settle down and create routines. This leads to formalization of rules, creation of stable structures, and the design of efficient and routinized activities (Quinn and Anderson 1984), a pattern that typically continues into maturity.

Stage in the life cycle may affect the type of leadership that group, or organization members feel is appropriate. In writing about self-managed groups in work organizations, Stewart and Manz (1995) suggest substantial leader initiative is critical at first, but as group members become more capable of self-leadership, it becomes less necessary. Quinn and Cameron (1983) imply that members of newly forming groups should more or less consciously feel comfortable with alternating emphasis between the leader and group initiatives, with founders' initiatives more prominent initially, followed by emphasis on group initiative, and then again with responsibility shifted back to a leader. Life-cycle literature also suggests the possibility that after being initially open to a variety of approaches to leadership, groups will formalize and routinize one approach (Quinn and Anderson 1984). In many organizations the type of approach routinized is bureaucratic, with clearly defined managerial roles (Quinn and Cameron 1983).

This suggests another dimension of the dilemma regarding leadership in feminist-based groups. Life-cycle literature implies that in newly developing groups there needs to be flexibility in the types of leadership exercised. In particular, it is necessary for leaders to take active initiative at first, gradually becoming less initiating so other members' initiative can come to the fore. Yet alternation between group and leader initiative may prove difficult in groups of women who, consciously or unconsciously, expect women to behave facultatively in leader roles. Moreover, the bureaucratic leadership that often emerges over time in organizations is also viewed as inappropriate for this type of group.

\section{Outcomes of Empowering Leadership}

The more or less explicit expectation of literature on empowering leadership is that group members will feel empowered. What this means in practice may vary considerably for different group members, depending in part on how they understand empowerment (e.g., as enhancing their individual skills or options, enabling participation in group decision making or in some other way, cf. Bartunek et al. 1996). Nevertheless, leadership that attempts to empower others should 
result in some kind of explicit recognition of empowerment according to whatever dimension's) group members wish to use. As noted above, such recognition should be particularly likely to occur during occasions of leadership succession, since these occasions activate conscious cognitive processing.

\section{Central Dilemma Revisited}

Taken together, literatures on women's work groups, empowering work groups, and organizational life cycles provide a conceptual frame for examining dilemmas associated with the exercise of leadership in work groups of women based on feminist principles and aimed at empowerment. Manz and Sims' (1980) discussion of empowering work groups suggests that leaders need to exercise leadership initiative to help members recognize their own power. Quinn and Cameron's (1983) discussion of stages of organizations suggests that initiative taking and facilitation should alternate as approaches, with leader initiative particularly necessary in early stages. But, leader initiative, regardless of whether it is task or process oriented, may run counter to a facilitative style that models the behaviors women seem to expect of one another in groups (e.g., Eagly et al. 1992, Valentine 1995).

This dilemma suggests the likelihood of considerable group member ambivalence about leadership. Leaders of empowering women's groups may enjoy their ability to take initiative, and at the same time have mixed feelings about doing so. They may think it goes against the premise of the group's principles to enjoy this exercise of power, especially if by taking power they seem to take it away from someone else. Other members of such groups may also be ambivalent about leaders' initiative taking. They may feel relief from not having to assume additional responsibilities if a leader takes initiative, but they may also feel disappointed in their lack of ability to influence the group.

\section{Leadership Successions as Occasions for Understanding}

Leadership succession is integral to organizations (Lundberg 1986, Virany et al. 1992), influencing their strategies, power distribution, information processes and performance (Alexander et al. 1993, Goodstein and Boeker 1991, Kesner and Dalton 1994, Kesner and Sabora 1994, Miller 1993, Pfeffer and Davis-Blake 1986, Smith and White 1987). Even under benign conditions, leadership succession is not simple; it typically evokes emotionally charged sensemaking processes for leaders and members alike. The act of choosing a leader may suggest a hierarchical situation even when the group is consciously egalitarian (Smith and Berg 1987). This may be particularly problematic in groups that focus on an egalitarian ideology (Jordan et al. 1991). Members of such groups may not wish to have some members in distinct leadership roles (Riger 1994).

Because leadership succession occasions are so highly emotionally charged, and because they require conscious deliberation, they offer a particularly good opportunity to explore how particular leadership styles are experienced in a group. Occasions such as these are particularly likely to provoke conscious engagement and active cognitive processing of events (Louis and Sutton 1991). Images and experiences come to the surface much more than during more routine organizational events.

How are such experiences and understandings indicated? There is a considerable literature showing that the types of images and metaphors people use to describe leadership (or other dimensions of organizational experience) are particularly good indicators of their understandings. Lakoff and Johnson (1980) considered metaphors the primary structuring and 
sensemaking device in life. Moch and Fields (1985) note that the metaphors people use to discuss events often reveal their underlying understandings and experiences of them. Chen and Meindl (1991) used metaphors as indicators of how the media portrayed Donald Burr's leadership of People Express. Sackmann (1989) indicated that metaphors provoke vivid images that make future actions more tangible and connote meanings on cognitive, emotional, and behavioral levels. She added that they influence organizational members' thinking, feelings, and constructs of reality. Lies (1993, p. 60) comments that metaphors are "a way of expressing ideas and feelings without spelling them out, and of transmitting the indescribable." Palmer and Dunford (1996) suggest how prevalent metaphors are in organizational research. Srivastva and Barrett (1988) and Brink (1993) make similar arguments. It is a reasonable assumption that the metaphors embedded in leadership succession discussions provide a window into ways group members experience leadership in their work group.

\section{Research Questions Revisited}

We address three research questions to explore the dynamics and dilemmas associated with leadership and leadership succession as they occur in women's groups designed to be empowering. First, we explore the ways members experience leadership during leadership succession processes. What images and metaphors of leadership are used on these occasions, and what do they suggest about the exercise of leadership in the group?

Second, what are the dynamics of leadership succession in such groups? We pay special attention to the leadership dynamics made salient by our literature review. Do they remain consistent over time, or do they evolve over the lifetime of the group? What ambivalences and dilemmas arise, what do these suggest about leadership in the group, and how are these played out in leadership succession situations?

Third, what happens to members' empowerment as a result of particular leadership processes? How is group members' sense of their own power expressed?

Addressing these questions enables a greater understanding of dynamics and dilemmas likely to be associated with leadership in women's groups that are designed to be empowering. It also illuminates larger issues of ambiguity, dilemmas, and contradictions (e.g., Hatch 1997, Quinn and Cameron 1988) surrounding the exercise of leadership in many organizational settings. Based on the research addressing these questions, we will suggest propositions that describe 1) processes likely to occur in conjunction with leadership in women's groups aimed at being empowering, and 2) actions that may be effective in dealing with dynamics and dilemmas encountered.

\section{Methodology}

\section{Data Collection}

We explored the dynamics associated with leadership and leadership succession in the NFDC from both insider and outsider perspectives (Bartunek and Louis 1996). The first and second authors are outside researchers. The third author is an inside researcher, one of the founders of the NFDC and a member of the NFDC during its first six years. She kept extensive journal notes of events occurring there. The first author was an external observer at NFDC meetings from their beginning until the seventh year of the group. She interviewed the founders prior to the beginning of the NFDC, took as close to verbatim notes as possible of what was said 
during each meeting, collected working documents, and tape recorded a session near the end of each meeting in which members of the group reflected on its high and low points. Shortly after the first leadership succession process, the first author, the founders of the group, and their first successors wrote a short paper about it. The second author joined the research team after the data were collected, and provided a totally external perspective on the group's events.

\section{Data Analysis}

We reviewed all the notes taken regarding the NFDC, starting with the interviews with the founders prior to the beginning of the NFDC and through its first six years. From these notes we first summarized the tasks in which the NFDC was engaged each year; these provided a necessary context for leadership and leadership succession. We then extracted all the materials from each year that addressed leadership succession. This process resulted in approximately 45 single-spaced pages of material, much more from the initial years when the leadership succession processes were more protracted than later.

Next we content analyzed the material gathered. To address the first research question regarding the ways members experienced leadership during leadership succession processes, we coded the metaphors and images used, as well as the contexts in which they were used and their meanings to group members as these were expressed in the group. To address the second research question regarding the dynamics and dilemmas of leadership succession, we developed descriptions of the discussion occurring during each leadership succession process. Some leadership succession decisions were lengthy; for these we prepared summary descriptions. Some were very short; for these we present the discussions in their entirety. To address the third research question asking what happens to members' empowerment as a result of particular leadership processes, we extracted conversations related to empowerment as they emerged in conjunction with the succession process or related discussions of leadership. We will present in our findings several excerpted quotations from the interviews, leadership succession discussions, and other relevant sources that are pertinent to these questions. We number each excerpt to facilitate later reference.

We divided the tasks of the content analysis. The third author carried out initial coding for the images and metaphors used (Question \#1), and the first and second authors checked the text for agreement with this coding. The first author developed the initial description of leadership succession discussions (Question \#2) and coded mentions of feelings of empowerment (Question \#3). The second and third authors then checked these for accuracy. Thus, both insider and outsider authors took primary responsibility for different parts of our analysis.

In most instances the three authors agreed on the descriptions of events that occurred (although the insider author remembered some events in the group more vividly than the outsider authors did). We occasionally disagreed on the meanings or implications of particular events. When this happened, we discussed our differences until we found ways of describing meanings that all three of us agreed on. This process of reaching agreement on interpretations is important. In many studies of group processes or other organizational events an outside researcher does all the interpreting of meanings of events (Bartunek and Louis 1996). As a consequence, reports of the studies may not describe members' experiences and understandings very well. In this case, however, the interpretations are those of both outside researchers and an insider member. This adds to the validity of the findings.

We begin our presentation of our findings by describing the founders' philosophical framework and approach to leadership. We then summarize the tasks the NFDC was engaged in 
during each year of our study and describe the leadership succession discussion that took place each year. When relevant, we also include events that occurred in conjunction with the leadership succession process but outside meetings where it was discussed. Since the leadership succession discussions were more extensive during the first two discussions than during the three subsequent ones, we devote proportionally more attention to the first two discussions.

\section{Findings}

\section{The Founders' Philosophical Framework}

For several years the founders, who were administrators and former teachers in the Network, had been concerned about the development of women as powerful teachers and agents of change. This involved two dimensions. First, they believed that teachers and their experiences can provide the most crucial and valuable knowledge base for educational inquiry, research, and theory. Thus, improvement of education hinges on encouraging teachers to bring their experience to the public realm. Secondly, they believed that teachers, typically isolated in their work and devalued by the general public, need opportunities for community that can foster more value being placed on their work. They concluded that teachers need time and space to build relationships with other teachers so that they might tell their professional stories, hear others' stories, discover commonalities and recurring themes in their work, articulate challenges and problems, collaborate toward innovations and solutions, and celebrate successes. In so doing, teachers would become aware of the knowledge they have gleaned from their work, of their capacity to reinterpret their experiences to critique and make meaning of them, and of their power to imagine new ways of educating. From this affirmation of the value of their own insight emerges a desire to communicate it to wider audiences.

As the founders designed the NFDC, they wanted three things which they termed, however loosely, "feminist" to characterize its processes and projects: (1) they would honor, respect and begin with the knowledge base of teachers rather than that of outside "experts"; (2) they would seek to articulate, authorize, and incorporate narrative language and subjective truth in their work; and (3) they would count on the power of collaborative relationships to test the subjective truth released through narrative and to reinterpret its meaning for the communal work of teacher empowerment and educational reform.

The founders viewed their own leadership within and beyond the NFDC not as instrumental toward the accomplishment of predetermined tasks but as empowering by releasing and enabling the agendas of ever more inclusive circles of teachers. In NFDC meetings in particular, the founders did not want to fulfill their own predetermined agenda. Rather, they wanted the group to work together collaboratively and democratically, so that together members could release their own agendas for the group and then for their colleagues in the Network. Moreover, they hoped that the operating mode of the group would serve as a model worthy of emulation in the larger Network.

The founders had implemented an early version of this idea in a very successful "think tank" held for Network teachers in 1987. The first members of the NFDC had all participated in that think tank. The experiences that had most stood out for them there were that the teachers there had "gelled" as a group, that they accomplished a good deal of work, and that they were being given an opportunity to contribute to educational reform. It was the outcomes of Diane's and Catherine's leadership style, not the style itself, that was most salient to the teachers who joined the NFDC. 
Once it began the NFDC met for about three or four days, usually three times a year, to conduct its work. They extended their approach and philosophy to other Network teachers primarily through two mechanisms they designed and initiated. First, they sponsored an annual refereed journal of teachers' writing, the Network Journal of Education (NJE) to which all faculty members in the Network could submit articles. Second, they conducted a series of faculty institutes aimed at bringing teachers from each Network school together to develop proposals for faculty development on a Network level. Each successive Institute sought to develop and actualize proposals designed by teachers at prior Institutes. By several measures reported on elsewhere (Bartunek et al. 1999), the NFDC's projects were successful in empowering teachers on personal and professional levels. In this paper, however, we turn our attention solely to the dynamics associated with exercising leadership within the NFDC.

From its second year on, on an annual basis, subsets of the NFDC's members rotated off the NFDC to be replaced by new members. This rotation took place at the NFDC's last meeting each school year. Decisions about leadership succession also took place at this meeting.

\section{The Founders' Approach to Leadership in the NFDC}

Prior to the beginning of the NFDC, the founders (who, even though they now held administrative positions, had been teacher advocates for several years) worked to flesh out how they would exercise leadership in a group they were instrumental in forming but that they wanted to belong to teachers. At first, they felt that they should stand back from taking a direct leadership role. One of the founders said several months before the group began: (1) "The question of leadership may come up in the first meeting. What if they ask us to be chair? We have to say no; otherwise, we'll break the vision that teachers can be agents of change."

However, during the summer prior to the beginning of the group, this founder attended a conference coordinated by Peggy Macintosh, of the Stone Center on Research on Women at Wellesley College, and changed her mind about the appropriate role of the leaders of the group. Peggy Macintosh advised her not to hesitate in becoming a leader and in playing a strong leadership role as the group began its work. She said she had seen too many women's groups flounder for lack of a strong foundation in feminist principles that leaders could have provided. She advised the founders to take formal leadership in the group and to do so collaboratively for the first few years, until collaborative and empowering processes could be introduced and operationalized. Then everyone's authority could be enhanced. The other founder agreed with this approach. She said that in other committees (2) "I shy away from leadership and then get frustrated. If we've conceived this from a feminist theory base, then we want to continue to exercise leadership, ensuring projects are imbued with principles we think important."

\section{Leadership Tenure}

At the first NFDC meeting (October, 1988) its members decided that the founders would lead the group for two years, and then, flying in the face of conventional practice, remain as group members in nonleadership roles. All the original members agreed to remain on the committee for the first two years, and then begin to rotate off. Two members would rotate off after two years, three members after three years, and the remaining two original members would stay on the committee for four years. Subsequent members would join the committee for a three-year term. Table 1 outlines NFDC membership over the course of the study as well as several other events pertinent to our analysis. These include the focus of the NFDC's work each year, significant events during each leadership succession process, and images and metaphors used during these processes. (Other than Diane and Catherine, all names are pseudonyms.) In a deliberate attempt 
to counter the norms of hierarchically structured groups, the committee did not decide in advance the form the succession process would take and which members would rotate off the committee after the second year.

\section{The First Two Years, Including the First Leadership Succession Decision (1990)}

During the first two years of the NFDC, much of its work focused on organizing itself, initiating the NJE (published for the first time in Spring, 1990) and first Faculty Institute (which took place in November 1989 and involved about 60 teachers). Both were quite difficult to accomplish, in part because the NFDC depended on funding from the Network office for them, and in part because there was little precedent for Network teachers initiating these types of activities for the Network. The NFDC had thought that the NJE would be approved readily by the administrative oversight committee that had approved its own funding and in doing so implicitly approved the journal. But, this committee questioned the expense of the NJE, wondering whether teachers would actually read it. This upset the NFDC members considerably and required them to develop extensive justification for the NJE. The Faculty Institute, too, encountered problems because unforeseen events necessitated a sudden increase in the funding for which the NFDC depended on the Network Director (Bartunek et al. 1992).1

The founders worked hard to collaborate with each other during the first two years of the NFDC, spending several hours before and after meetings planning and debriefing together. They designed and initiated several processes for the NFDC meetings that they felt would empower the members. For example, they started meetings with the sharing of professional narratives to tap the knowledge and expertise of the members for group work. They consciously left the agendas for the meetings somewhat open, so members could participate in shaping them. They did not direct the discussion at the meetings, but opened up topics to member discussion. They provided opportunities at the end of each meeting for group members to reflect together on what had gone well, what had not, and implications for the group. The group seemed to work very well. In fact, some NFDC members during this time referred to the founders' exercise of leadership as "magical."

During its second year (January of 1990) at the NFDC meeting following the first Faculty Institute (Bartunek et al. 1992), time was set aside to discuss the first membership rotation and leadership succession. Discussion about succession would begin on the third day of the meeting, after work dealing with the proposals from the Faculty Institute had been completed. The succession decision would be made in conjunction with the decisions about which members would rotate off the committee.

During the evening of the second day of the meeting, one of the founders, Diane, decided to leave the NFDC rather than simply to rotate off its leadership. She told Catherine of her decision. She gave several reasons, including being overextended at work and feeling that the prior meetings of the group had been difficult for her.

The next morning was set aside for the group members to decide who would rotate off the committee and who would remain. The expectation was that of the seven current members, two or three would rotate off to be replaced by new members. Diane announced her decision to leave the committee. This announcement was emotionally difficult for the group members, most of whom were stunned. They spent time discussing her decision and their sadness with it. Eventually, they returned to discussing a rotation of group membership, and decided that four of the members would remain on the NFDC and three-Diane and two others-would rotate off. 
In the afternoon the group took up the discussion of leadership. Because the group accepted the premise that the founder remaining on the committee would not be in the leadership position, three members remained as potential leader(s). After a discussion lasting all afternoon, the group eventually moved toward a reaffirmation of coleadership as consistent with the collaboration central to the founders' philosophy. The discussion became increasingly awkward, as it became evident that two of the three candidates would become leaders and one would not. Time passed as no one (or two) presented herself as a successor. This lack of presentation occurred in part because, as Joan said later, she was (3) "struggling with wanting to be a coleader, but wondering whether I could possibly measure up." But she did not publicly voice this struggle, and the lack of initiative taken by the candidates led Diane to become upset at the group, saying (4) "I didn't bargain on this. I thought there'd be people interested in doing this."

The group decided that each coleader would serve a two-year term, with one new leader each year and one experienced leader. To begin the rotation, one person would serve as coleader for one year. The group saw this yearly shift in the leadership team as a way of building on the experience of its leaders, yet invigorating the collaborative model with new insight each year. After public testing of the three candidates' desire for leadership, Joan volunteered to serve as coleader for two years and Barbara volunteered to serve as coleader for one year:

(5) Joan: I'm ready to say I'd be willing to take on a leadership role. I think there are enough people interested in the journal, and (taking) on more of a leadership role. . . So. Okay.

Barbara: I'd be willing to do it one year if we wanted to do it 2 and 1.

Joan and Barbara were anxious about becoming coleaders. They had not worked jointly on NFDC tasks in the past (Joan was an editor of the NJE and Barbara had worked on the Faculty Institute). Moreover, they did not know each other as well as the cofounders of the group did.

The discussion and decision were followed by a reflection period during which group members spontaneously reflected on what the founders had meant to them and how positive their experience of the founders' leadership had been. For example, Barbara commented:

(6) I don't like this change, and, but, you know, to me something that has just gone well ... is that, I didn't use the word panicky loosely when I said that about Diane saying she was going to go off the committee. . . My feeling was the child who needs the parents to do it, who loves the way the parents are doing it and knows what the parents are doing and needs it and to me part of what went well was that after that panic and after that horror and after that awfulness, for me, we were able to sit around and talk about leadership ....

After the meeting ended, Diane told the first author: (7) "I was shocked (that no one took the initiative to become leader). I thought there'd be more interest. . .. I felt like 'where's your dedication,' and 'this is why I'm leaving,' partly." She later added that she had said this because of feeling overburdened with responsibility for the NFDC ("no one would pick up the torch if I left") and a sense of failure ("this hasn't been empowering to people; no one wants to lead").

In April 1990 the founders and their successors met together to conduct a formal leadership transition. The successors first met by themselves for one and one half days, during which they created a working and personal relationship, defined for themselves the philosophical basis of their approach, and decided how to divide responsibility to guard both the work and the process of the committee. Then the founders and their successors talked together about the philosophy of the NFDC and the successors planned the first meeting they would lead. During 
their meeting, the successors realized that they had internalized the values and premises instilled by the founders. Barbara recorded notes about this session in which she commented:

(8) The astonishing things that emerged from the day were a feeling that we really did know what the work was about, understood the process or model on which the work was based . . . and that we could do the job we'd undertaken. We were also pleased to find that we would work very well together .... O One major question had been whether (the NFDC) could survive a change of leadership or whether Catherine's and Diane's vision, personalities, and deep friendship were what was really at the heart of it all. With the understanding that they are really responsible for the committee's design and goals, we were pleased to know the work can continue under new leaders.

During the meeting Barbara wrote a poem about the founders (shown in Figure 1) in which she reflected metaphorically on what they had meant to her and the NFDC. In this poem she ascribed several "mythic" properties to them: Pathfinders, Netcasters, Firebringers, and Torchbearers. The last two stanzas indicate an interesting shift in the attribution of agency from "you" (the two original leaders) to "we" (the first successors, and possibly, all the committee members). The Firebringers have brought fire to people, but it spreads now "spark by spark," "flashing back" interactively. The torchbearers have let the light shine, but "Clearer now, we see where the path may lead," and with the torchbearers, "we can build bridges . ..."

\section{The Second Leadership Succession Discussion, 1991}

The NFDC met in August and November of 1990, February of 1991, and April 1991, when the next leadership succession decision was to be made. During this year the focus of the group continued to be on the development of Faculty Institutes and the publication of the NJE. Some NFDC members worked with other Network teachers to plan the second Faculty Institute, which would take place during the summer of 1991. Others worked with yet other teachers on the next volume of the NJE.

Barbara and Joan continued the founders' leadership model. This was very complicated during the 1990-1991 school year. They perceived early on that one of the new NFDC members was abusing alcohol during the meetings. At their November meeting, Joan, who was experienced in this type of work, helped the group conduct a formal "intervention" (Johnson 1980) with the member who had the drinking problem that resulted in her going into treatment (Bartunek and Lacey 1998). Many of the NFDC members said at the time that they experienced the intervention as very successful, increasing their cohesion and sense of self-efficacy. They had found the courage together to act in a way that was powerful, loving, and successful.

Just prior the November meeting, Barbara wrote a letter to Joan and the first author in which she reflected on some of the paradoxes associated with the collaborative leadership process the founders had modeled and which they were attempting to emulate. Barbara commented:

(9) (I've become aware of) how carefully the group is looking at us as their leaders. Realizing this started me thinking about what I think is a paradox, or even a contradiction, in the way we're defining collaborative leadership . . . The way leadership is set up now, collaborative leaders means, in reality, the two leaders collaborating, not really a sharing of leadership among all the members of the group . . . I wonder if we haven't created a mystique of leadership on the committee, which we might examine, to see if there are ways of lessening it. 
At the second leadership succession discussion in April, Barbara distributed the letter she had written. Joan raised the issue: Did the explicit designation of herself and Barbara as collaborative leaders create a separateness between them and the rest of the members? What did this say about the group's power balance? Several other group members mentioned the discomfort and even fear they felt in taking on the leadership role because they were not sure if they had the ability to carry on the vision of the founders. Joan discussed the ambivalence she felt over enjoying the prestige and power that came with being a coleader.

(10) When I think of it, the co-leadership is we'll have a very special collaboration between the two of us and the others arc less special ... (co-leadership) is an image of our separateness from the others ... What (our discussion points) up quite painfully is the power imbalance. And I enjoy it. I like being queen of the universe. I'm pretty responsible and I like doing this. That's the painful part for me ... There's something that doesn't have integrity in terms of what we're supposed to be about.

The phrase "queen of the universe" became a humorous and ironic way to capture the power associated with the coleader role, and, later, the lack of power associated with it.

Joan and Barbara asked if there was a way to design a new leadership structure that would encompass all the members. The group discussed this, and eventually Doris, whose job involved conducting group dynamics laboratories in which middle school students rotated leadership responsibilities for different tasks, suggested that the NFDC use a similar procedure. After considerable discussion about ways to increase ownership and responsibility for the committee among the members, the group decided to replace the coleader model with one in which shared leadership functions would rotate between meetings. Different members would be responsible for different aspects of the upcoming meeting (agenda, hospitality, the narrative, etc.). Decisions about who would be in charge of each aspect of a meeting would be made at the end of the prior meeting. In addition, one member would have a one-year appointment as coordinator. Her primary responsibility would be to act as liaison with the Network office. The group decided that Joan would remain on the group for a fourth year and fulfill the group's coordinator role for the next year. The part of the discussion in which the decision was made that Joan would be coordinator went as follows:

(11) Barbara: Should we talk about what the coordinator would be responsible for?

Joan: And who it would be?

Evelyn: But we'd like to give it to you.

Joan: Okay. But next year will be my last year.

Catherine: I don't think it makes any difference. We're in an experiment. Hopefully, we'll all get experience as we rotate responsibilities.

At this meeting the NFDC members confronted a leadership structure that was out of alignment with the group's principles and had changed it so it took a form that had more integrity for them. The structure they created at this meeting would endure in the group throughout the time of data collection. 
At the end of the meeting the group reflected on the new model of leadership they had just developed. Colleen raised some potential implications she saw for the group:

(12) I think that one of the implications I see is that . . . in between the meetings I see the ownership changing. To me just from a selfish viewpoint I can see that's going to mean more anxiety in between the meetings. I think we're going to end up sharing the anxiety of the codirectors, their burden. I'm not sure I'm happy about that, to be honest.

Images and metaphors from this second leadership succession discussion reveal the group's questioning of the appropriateness of leaders "separated" (10) from the group because of a "mystique of leadership" (9) which had been developing. The "power imbalance" (10) needed to be addressed if "integrity" of mission and action was to be preserved. The committee used contrasting images of "ownership" (12) and "queen of the universe" (10) to wrestle with the incongruities they experienced and wanted to redress by "sharing the burden," "sharing the anxiety." (12)

\section{The Third Leadership Succession Discussion, 1992}

During the 1991-1992 school year, the NFDC initiated its new leadership plan. The coordinator served as the NFDC's liaison with the Network office, and leadership of the meetings was divided among the members for each meeting. This seemed to work well for the group, which entered into an intense task-oriented stage of developing the proposals submitted by the teachers who had attended its two successful Faculty Institutes to date. The committee had established credibility in the Network as a strong group with successful projects; it now joined other committees in the Network in developing three- to five-year plans to accomplish its mission.

As plans were expanding, however, resources available in and from the Network were shrinking. In anticipating the latter, the Network had hired a development director to seek support from external agencies for national-level projects characteristic of the Network in general. This director saw the NFDC as skilled in developing these kind of proposals, and began to work with NFDC members to write grant proposals for its many ideas, such as a third Faculty Institute to take place in the summer of 1993, a plan to link the schools electronically, support for teacherresearcher groups, and more. As grant submissions were rejected or delayed, anxiety about the availability of funding of the committee and its projects increased. NFDC members began to get upset at the amount of time they were now devoting to grant writing, and relations with the Network Director were strained at times as committee members felt insecure about the level of the Network's commitment to support their work with teachers, whom they feared to be low status in terms of priorities. Vulnerability grew as the group attempted to voice its concerns with the Network Director and did not feel adequately responded to. As a result, the salience of a good working relationship with the Network Director increased; members brought this awareness to the third leadership succession discussion.

In the NFDC's April 1992 meeting, one year after the group shifted from coleaders to shared leadership with a coordinator, the members discussed the choice of their next coordinator. The conversation was quite different from the prior year, and much more pragmatic. Leadership and the "integrity" (10) of the group's structures for the exercise of truly collaborative leadership were no longer central issues for the group. Joan, who would be leaving the group after this meeting, summarized the coordinator's responsibilities. Conversation centered around the best way to communicate with the Network Director. Then the group selected its next coordinator. Because the actual decision process was brief, we present it in its entirety. 
(13) Joan: Okay so now people know what the job is. Who'd be willing to do it?

Sara: Colleen, you seem a natural and Doris is doing the journal.

Colleen: I'd be willing to do it.

Meg: And I'd be happy if you do it.

Catherine: You'd be excellent.

Colleen: I get along with (the Network Director) and can play very dumb.

Doris: Good for you. (They all clap.)

Catherine: A new queen.

Colleen: No, I don't have queenly qualities.

. . .Doris: And your chair broke (referring to an incident at an earlier meeting when the chair Colleen had been sitting on had collapsed.)

Catherine: And all your friends picked you up. And thank you to our past queen.

In the NFDC's reflection on the leadership succession decision, one of the group members commented that it was significant that Colleen was interested in taking the coordinator job, and felt her interest showed a building of confidence. Colleen agreed that she felt more self-confident now than she had before, and added that she would not have been willing to take the position six months earlier. Images and metaphors during this discussion (13) reveal that the queenly role had been broken; the coordinator no longer had "queenly qualities." Instead, she could "play dumb," and count on her friends to "pick her up" should she fall down.

\section{The Fourth Leadership Succession Discussion, 1993}

During the 1992-1993 school year, three NFDC members worked with three Network administrators to plan the next Faculty Institute, to take place during the summer of 1993. Contrary to the prior two Institutes, this one included both teacher and administrator participants and was viewed as the first stage in a multiyear project. This Institute would lead into regional institutes the next two years. Since the NFDC was collaborating with an administrators' committee to plan the Institute, the Network Director led the planning process as chair of the administrators' committee. The NFDC members were disturbed at the comparatively hierarchical mode of leadership and organization exercised at the first meeting, which differed considerably from the tone of their own meetings. They dealt with their concern in a conference call in which they strategized some ways Colleen might approach the Network Director. Subsequently, Colleen told the Network Director about her concern with this discrepancy, and the Network Director changed her approach to be more collaborative.

Later that year, the NFDC met with the administrators' committee that provided funding for its activities and with some of the committee members with whom it was working to plan the upcoming Institute. The NFDC members prepared ahead of time to ensure that the process of this meeting would mirror their own collaborative processes, and the meeting was quite successful. During the year the NFDC also worked to enhance its communication with teachers in the schools. 
Finally, the group formalized its more routine procedures; Colleen presented as a parting gift to the group a manual that described typical procedures the NFDC used in conducting its affairs.

When the coordinator succession discussion occurred during a meeting in May of 1993, Colleen started the conversation by talking about her responsibilities as coordinator:

(14) I think you can see that the coordinator's job has changed immensely. I think that is a very rewarding aspect of the last couple years, in that we have weaned ourselves away from the coordinator being the queen. The job as I see it now is basically a job where we need a liaison with (the Network Director) and, I guess others in the Network in general. I've tried to be in that relationship, not begin it, but take what we had before and refine and communicate it.

One of the members of the committee commented on the coordinator role, which led to a brief discussion of the type of leadership it involved:

(15) Doris: We purposely are downplaying the job in terms of any kind of head or leader.

Meg: But you do have the outside responsibility.

Colleen: I didn't feel that way, because we've become so united as a committee.

Doris: Anytime something has come up we've made a decision together.

The group then discussed who should take on the coordinator role. Again, the discussion is presented in its entirety.

(16) Meg: I'd like to nominate someone, to ask Sara if she'll do it. I think she has an excellent relationship with (the Network Director) and a gentle, wonderful way of expressing herself.

Catherine: I second that.

Sara: Thank you. I appreciate your affirmation. I'm scared to death.

Dana: You'll be fine.

Sara: I think this is a new step in my life.

Colleen: It's a very rewarding experience. You're working with people beyond the community of this table. . . My only advice is to redesign the job in the way that you feel you'd be comfortable in the job. At first I thought I had to do it the way Barbara and Joan did, but then thought the job had to be redefined because I wasn't Barbara or Joan. You should bring your talents and creativity to the job.

Sara: That's a most helpful thing, and this committee has changed with every person. We can't recreate what has been.

Meg: Yay Sara, (everyone claps). 
A sense of comfort and security is embedded in the metaphors of this discussion. The "community of this table" (16) has grown more confident through the year in its being "united as a committee," (15) capable of making decisions together and in agreement about its routine modes of proceeding. The new coordinator, although "scared to death," seems to understand that she stands on firm ground for this "new step" (16) in her life. The group, in general, has been "weaned" (14) from a leadership oriented toward initiative taking for empowering group members; the coordinator can redefine and redesign the role in a way that fits her talents and creativity.

\section{The Fifth Leadership Succession Discussion, 1994}

During the 1993-1994 school year, the NFDC was busy consolidating the outcomes of the 1993 Institute and planning for the regional institutes that would occur in the summer of 1994. They worked during the year on grant proposals, on developing a means for experienced teachers to travel to different Network schools to make presentations, on using the talents of prior NFDC members, and on storage and archives for documents. They continued building computer links among the schools and they worked with the Network Director to get their ongoing funding stabilized. During this year an evaluation of their impact on the Network was conducted (Bartunek et al. 1999), the results of which suggested that the Network had had very positive impacts on teachers who had participated in their activities, but that many Network teachers were not familiar with the group's work. The group worked on ways to understand the implications of the evaluation for the future of its mission and work.

The fifth leadership succession occurred in May 1994. By this time, as suggested by the reflections above, the NFDC viewed the coordinator not so much as a leader, but as external liaison. During this leadership succession discussion, the group joked about the coordinator primarily needing to know when to "go wailing" (17) or speak up with the Network office on behalf of the group The discussion then moved to who wanted to be coordinator. This time the first person nominated did not accept the position:

(17) Jackie: I'd like to see you (Meg) coordinator next year. I think you will do a good job. You keep us on task, move us along, which is something we need.

Bonnie: And I think you know when to go wailing (to the Network Director) and when not to.

Sara: How do you feel about that?

Meg: I'm not sure . . . . It would be dealing with the Network Director. I'm not sure I'm the most astute person to do that. I think I'm better with the group. I could do it, but I'm not sure I'm the best.

Jackie: I think you can do it.

Catherine: I think you know when to wail and when not to, and have an incredibly wonderful sense of humor that works well within the group.

Meg: Within the group (laughter).

Sara: I'm not gonna say much about it, because I think you can do it. I also know your reservations. I think you need to discern whether you want to do that. 
Meg: I think I don't. I think it'd be better for the group if I didn't. I would love to, but I think it'd be better for the group if someone else did it.

Catherine: Well, I think Dana would be a good chair . . . I think you're organized, you have a great way of bringing closure to things, you're extremely-you're very good at negotiating the real, and that might be a very good quality to bring in relation to the Network Director. And you're very positive.

Dana: It makes me kind of nervous.

Sara: How do you feel, Dana?

Dana: I have a good relation with (the Network Director), and I'm sure I could call Sara up.

Sara: You could always call me.

Dana: I mean, you know, I guess what-I know basically what you (Sara) did, I think that I could do it, but I also think that you, Meg could do it, but I understood what you're saying. I wasn't there for some of those things that happened before.

Sara: And that's good. Because it's easy to fall into that mode of remembering of what has gone before and allowing it to color what you're looking toward. The fact that you haven't is good.

Meg: Great.

Dana: (To Meg) Are you sure you don't want to do it?

Meg: I'm very sure.

Dana: Okay.

Sara: The queen is dead, long live the queen.

In this final leadership succession discussion considered here, the NFDC seems so in agreement about what the role entails that it can accept with equanimity one nominee's candid assessment that she could better exercise her "astute" (17) leadership internally than externally. The queen is dead; long live the queen/coordinator without the long lineage of memory that might "color" relations with the Network and its Director. A certain acceptance of its subsidiary status in the Network seems in evidence; it accommodates by choosing a coordinator who will know when to "wail" for its needs and when not to do so. A new emphasis seems to be emerging: the committee chooses a leader who will best keep the group "on task" and out of the consciousness of the Network, except when absolutely necessary.

\section{$\underline{\text { Analysis }}$}

We have set out to address several intertwined research questions: First, how is leadership experienced? Specifically, what do the metaphors and images of leadership that emerged during these leadership succession discussions suggest about the exercise of leadership in this women's group? Second, what are dynamics of leadership succession that 
occur in a women's work group designed to empower its members, and what do these suggest about leadership? How, if at all, do these dynamics evolve over time and what dilemmas, ambivalence, and contradictions do group members experience when women leaders exercise initiating and/or facilitative forms of leadership? Third, what do the succession discussions disclose about the implications of these dynamics for the empowerment that members feel? We discuss each question below.

\section{Experiences of Leadership Reflected in Images and Metaphors}

During the NFDC's first five leadership successions, the images and metaphors in use shifted dramatically over time. Images associated with leaders and leadership styles evolved from the magical and parental (6) Pathfinders, Netcasters, Firebringers, and Torchbearers (Figure 1), to the separate (10) and mystique-laden (9) collaborators, to the ironic and ambivalent queenly (10)/unqueenly ones (13) of the universe, to the equal and responsible owners (12), and to the pragmatic and perhaps accommodating wailers (17).

The founders both initiated processes and enacted facilitative styles of leadership. In the interest of incorporating feminist principles into the life of the committee and by grounding the committee's work in their own knowledge, insight, and desires, they attended to, initiated, and attempted to model leadership behaviors that they thought would empower members. As a result their leadership was strongly admired, seen as mythical and magical, but also very difficult to follow and sustain. Those who succeeded them as coleaders reflected the doubt that other committee members also voiced: was the group's vision, its sense of progress, of empowerment, due to group members' own agency or the magic and charisma reflected in the leadership styles of the first coleaders? Their successors desired to emulate them at the same time that they feared that they would not be able to follow in their footsteps.

Barbara and Joan eventually felt they had understood and could carry out the founders' vision. But it was not far into their tenure that Barbara pinpointed a crucial inconsistency in the founders' (and now their own) exercise of leadership. The mystique of leadership was associated with the leaders' separateness from the group, with a too sharp delineation of roles and responsibilities from the rest of the committee. This separateness was problematic for members of a group that valued connectedness and collaboration.

Ambivalence about leadership in the group was best expressed in the humorous and ironic term, "queen of the universe," whose usage occurred originally in the second leadership succession and then in two of the three later leadership successions described here. (The term was used by group members on several other occasions as well, e.g., (14).) Hatch (1997) shows how ironic humor is a good way of expressing contradictions in a given situation. She notes that crucial characteristics of irony include an opposition between what is said and what is meant, as well as a juxtaposition of incongruent images, characteristics, frameworks, or events. Ironic remarks enable researchers to pinpoint aspects of experience that are constructed as contradictory by those producing or responding to the remark.

The term "queen of the universe" represents an interesting juxtaposition of an extremely powerful stated role with a situation in which the members of the group not only feel ambivalent about how much authority they may exercise within their group, but also feel relatively powerless with respect to the Network itself. The power of a leadership role is even more downplayed in Colleen's concern (13) that she did not have queenly qualities. In this excerpt the other members remind her that her chair broke, but that they picked her up, thus suggesting that there was not a great power differential. 
Less than a year after the first leadership succession, the group met their ambivalence head on and developed the rather ingenious solution of rotating leadership roles continually within the group, a kind of distributed leadership (Gastil 1994), although the group did not use that term. They expected that this sharing of leadership functions would both increase ownership and ease the tension they were experiencing with leaders who were both active and often apart in analyzing and designing group processes. This solution required reducing the coordinator's initiating power vis-a-vis the group's own tasks; that responsibility now lay with all of the members collectively.

After this switch in authority structure however, the images found in subsequent leadership succession discussions disclose a progression in this emptying of power from the coordinator's role, as the queen of the universe (10) became, happily, unqueenly (13), and as the coordinator was asked to "play dumb" (13) for the group and "wail" (17) when needed. One of the group members put it succinctly in the fourth leadership succession, stating that the coordinator role involved "downplaying the job in terms of any kind of head or leader" within the group (15) and, instead, merely helping the group "stay on task." The women in this group had succeeded in easing their ambivalent assessment of the value of the initiative-taking behaviors of the founders and their first successors within the group, but in the process had shifted the focus of their designated leaders/coordinators away from attention to empowerment processes within the group to linkages outside the group, especially with the Network Director.

\section{Dynamics of Leadership as Reflected in Leadership Succession Discussions}

The discussions and events surrounding leadership succession in the NFDC disclose important dynamics associated with leadership. We address the following here: the relationship of leadership style to stages in the life cycle of a group; the ambivalence experienced by these women when leaders exercised strong initiative and/or when members perceived that the exercise of leadership separated those in leadership roles from the group; and, finally, the subtle shift that occurred in understanding the internal work of leadership within the committee.

Relationship of Leadership Style to Stages in the Life Cycle of the Group. The evolving leadership in the group, as reflected in its succession processes was somewhat consistent with what Quinn and Cameron (1983) describe as normal stages in the development of new organizations and what Stewart and Manz (1995) suggest is appropriate in the early development of self-managed groups. The initial focus was on the founders, and whether their successors could live up to their example of leadership (8). The leadership process developed at the second leadership succession was much more egalitarian and collective. After a time, this leadership process became routinized, although not in the bureaucratic form prevalent in many organizations; the form leadership in the group would take was no longer discussed in group decision making processes and a manual was written that described standard procedures in the group so they could be replicated easily. The leadership succession discussions reflected this pattern. From being very emotionally wrenching at first, a discussion that took much of an afternoon, the succession decisions moved, in later years, to a much less complex, more pragmatic process, one that took less than one-half hour. Part of the reason the leadership succession decisions became less complex, of course, was that they became focused on leader initiatives outside the group rather than inside it.

Dynamics emerged in this group, however, that differ in interesting ways from Quinn and Cameron's model. Although authority was initially centralized in the founders, it was exercised primarily in their initiating modeling behaviors that would develop power in others (Manz and Sims 1980). Modeling such behavior required leader distance from other members, however, which 
proved problematic. During the first succession discussion, each group member had to decide if she had "what it took" (3) to be directive, facilitative, and separate enough to ensure that empowering processes were at work in the group. This dynamic created enough tension in a group of women who valued connectedness and mutuality to move them to the decision at the second succession meeting to take collective ownership of the work of the committee. They would share the "burden" (12) of stepping back to lead the committee on a rotating basis-a move they felt to be different from the leadership style of the founders, but more consistent with, even potentially a culmination of, the founders' principles.

Perhaps to compensate for the looser form of coordination and communication, they began to routinize procedures through vehicles such as the development of a manual. Yet, they did not return, as the life-cycle literature suggests they might have, to a more bureaucratic form of leadership with designated centralized authority within the group. We leave them in this analysis continuing the practice of rotating responsibility for the meeting tasks, including the sharing of professional narratives, agenda formation, meeting facilitation, project planning, proposal writing, and external communications.

Ambivalence Associated With Taking Leadership. The leadership succession discussions give evidence of the ambivalence the group experienced in relation to the assumption of a leadership role in the group and/or the exercise of initiating leadership. From the founders onward, members of the group expressed strong feelings, both positive and negative, about assuming the role of leader. The founders felt great ambivalence in anticipation of assuming leadership of the newly formed committee. Even as it seemed inconsistent for them as administrators to chair a group born of the vision of teachers and designed to empower teachers (1), they wanted very much to influence the shape of the new entity in the light of feminist understandings (2). Conscious of the ambiguous nature of their roles as coleaders, they were acutely sensitive to signs that they had failed (Lacey et al. 1990). Diane manifested this most acutely in the first leadership succession discussion when no one stepped forward at first to assume the leadership role (7). She responded with anger and disappointment to this perceived "failure," even as other NFDC members spoke, also with some ambivalence, about how thoroughly the leaders had succeeded.

After overcoming their own sense of inadequacy in the realization that they had understood and integrated the founders' vision, the first successors sought to emulate the directive and facilitative behaviors of the founders (8). But one of them soon described this approach as paradoxical (9), as she experienced discomfort in the way it separated the leaders from the group. Meanwhile, even as she agreed with her coleader's insight about the "mystique of leadership" developing in the group, the other successor felt ambivalent about enjoying the power associated with the role (10). It was after discussion of these contradictory feelings at the next leadership succession discussion that the NFDC designed leadership of internal tasks in such a way that individual members rotated responsibilities on a meeting by meeting basis. This method reduced ambivalence about the overall amount of power in the group any designated leader would have by implying that there would not be very much (15), even as it acknowledged the increasing leadership capacities of group members as a whole.

The coordinator, working jointly with other group members (15), still was to take initiative, albeit from a subsidiary position, with respect to the Network Director and oversight committee. This shift from tensions associated with authority within the group to apprehensiveness about representing the committee's interests with external authorities provoked anxiety as well, as was reflected in Sara's commenting that she was "scared to death" about becoming coordinator (16). 
It is possible that the shift in the designated coordinator's focus from internal concerns to external communications may have helped the NFDC solidify their own group cohesiveness. Smith and Berg (1987) suggest that finding an outside cause or enemy is a common way to build group unity. By focusing on authority issues outside the group, members protected their empowerment initiative within the group and relieved their own potential inner conflicts about initiating leadership. NFDC members strategized together and supported their coordinator in confronting the Network Director more or less successfully on issues ranging from budgeting to her leadership style in joint NFDC/oversight committee meetings. The humorous and selfdeprecating use of such terms as "playing dumb" (13) and "wailing" (17) might ironically provide good indications that committee members were aware of the foil they had created to maintain internal connectedness in common cause.

Shift in Understanding of Leadership Within the Committee. We noted that women's work groups designed on feminist principles are characterized as attentive to group process. Explicit initiative aimed at creating empowering group processes occupied much of the founders' and first successors' time. They designed empowering processes and addressed process problems that arose during the course of group meetings (such as the alcohol intervention).

Explicit attention to process found expression in both the first and second leadership succession discussions. Group members devoted considerable discussion to how leadership should be designed and exercised, even before deciding who would best fulfill the role. In the second leadership succession discussion, moreover, group members tried to redesign leadership in a way that would be consistent with their process values.

However, during this second leadership succession discussion, a subtle and unrecognized shift occurred in the potential for group members to take initiative with regard to process issues in the group. When the group designed ways of dividing up leadership functions, they did so based on group tasks (narrative, facilitation for individual meetings, etc.). No one, after this leadership succession decision, had authority to confront process concerns within the group; confronting process concerns was not a "task" anyone had recognized.

Fletcher (1999) has found that relational processes in organizations often get "disappeared." It is difficult for people-women as well as men-to recognize the relational actions that enable a group to cohere. Even in the NFDC, a group that was paying attention to process, what was most salient for the members were the particular tasks of leadership. While the means they found of dividing the tasks of the group was, as we noted above, an ingenious way to reduce separation between leaders and other group members and to share responsibilities in the group, it did not include attention to the core value underlying the exercise of collaborative leadership in the group, initiative taken to foster empowering processes.

When this authority was lost to the group and style of shared leadership became routinized, dealing with leadership within the group became simpler. Initially prolonged conversations about leadership processes became much shorter. Leadership succession discussions took on a more pragmatic tone-a consideration of the qualities a coordinator would need to relate to the Network through its Director.

\section{Outcomes: Members' Empowerment}

The dynamics that occurred and the images used revealed implications for the members' empowerment. The founders clearly felt they had power, and that they were taking initiative in a way that would empower others. Their success in doing so led the other members to feel both 
empowered and successful in terms of the accomplishments that had been their aims for the group and more dependent on the founders' magic.

After their meeting with Catherine and Diane, Joan and Barbara felt empowered because they could understand Catherine and Diane's vision (8). But, Barbara was uncomfortable with the mystique of leadership (9) and Joan felt a bit guilty about having power (10). This led to the development of an approach to leadership in which power was distributed and rotated, where all shared authority and responsibility for tasks (12), where all felt empowered and where, unknowingly and ironically, the power to raise process issues within the group was taken away.

By the time leadership passed on to Colleen (13), she was focusing on power in relation to the Network Director rather than the group, and deemphasizing her power. By the time of the last leadership succession decision studied, the issue of power was entirely related to the Network Director, and the first person invited to take the position turned it down because she did not think she was the most astute person to "wail" to the Network Director (17). The group was not, during these latter occasions, discussing their sense of their own power; the implication appeared to be that they remained feeling empowered by the form of distributed leadership in their committee. The lack of ability of confront process issues never became salient.

\section{Discussion}

We began the paper with a basic dilemma: How can and should women leaders in a women's group designed based on feminist principles take initiatives aimed at empowering group members, especially if women typically expect other women to be facultative? The dilemma was reflected in the metaphors group members used and in their ambivalence about the founders' and their immediate successors' empowerment-oriented leadership that separated the leaders to some extent from other group members. The group members recognized contradictions associated with the structure and principles of leadership in the group. Their attempts to deal outright with and resolve these contradictions resulted in the development of a style of leadership that, on the surface, expressed their values, but in hidden ways undermined them. One of the results was that, over time, their images of leadership became much less powerful and the possibilities of taking initiative within the group were reduced.

These results were consistent with the conceptual understanding of the types of dilemmas likely to be faced by groups like the one we studied. They make evident that dealing with the dilemma we addressed is very difficult, and that attention to process issues is very hard to sustain (Fletcher 1999). The NFDC members were highly sensitive to process issues and worked hard to engage them directly, especially during their first few years. Nevertheless, in confronting process dilemmas regarding leadership, they inadvertently created a type of leadership that undermined their basic premises by diverting attention away from empowering processes and towards the completion of tasks. Although this was not recognized, the new leadership style severely limited the group's ability to address internal problems and to build the power and authority of teachers.

Rather than suggesting ways around the dilemma the NFDC encountered, on the basis of this study we suggest three propositions regarding (a) likely experiences of women's groups designed on feminist principles aimed at being empowering and (b) ways such groups may best live with the tensions that occur. Our propositions are pertinent to other change efforts as well. Our first proposition follows on the experience of the group. 
PROPOSITION 1A. Contradictions associated with leadership in women's groups based on feminist principles create process dilemmas.

Based on the results of this study it is not appropriate to suggest ways such dilemmas can be resolved. The results imply, in fact, that attempting to resolve these dilemmas may not even be desirable. Instead, it may be best consciously to acknowledge and live with the contradictions they engender. Handy (1994) suggests, for example, that paradoxes (and, implicitly, contradictions built into a situation) are better left unresolved than resolved. Perhaps the experience of contradictions regarding leadership is essential for the experience of empowerment in feminist designed groups aimed at being empowering.

PROPOSITION 1B. Women's groups based on feminist principles will be more effective to the extent that they leave process dilemmas associated with leadership unresolved rather than attempting to resolve them.

But, the experience of contradictions regarding leadership means that by necessity the groups will deal with considerable tension. There are too many contradictory pulls associated with conflicting notions of whether leaders should act as facilitative, initiating, or some combination of these styles for groups not to experience tension. Our second proposition suggests this typical experience.

PROPOSITION 2A. The more women's groups based on feminist principles experience process dilemmas regarding leadership, the more tension surrounding leadership they will evoke.

Is this a problem? It seems likely that explicitly articulating and valuing the tensions, something the NFDC did not persist in doing, can lead to more creative empowerment attempts than attempting to carry out only one consistent type of leadership style and/or implicitly assuming that contradictions are bad. For example, Moch and Bartunek (1990) proposed that consultants and others who wish to create transformation in their organizations need to be simultaneously directive and facilitative. As was suggested to one of the founders of the NFDC, they needed to take initiative to model empowering ways of acting. But, they needed to be facilitative at the same time, encouraging members' development. In other words, to the extent that leaders of empowering groups (and other group members as well) can hold tensions between the two conflicting sets of approaches, the more empowering the group will be. Perhaps a form of leadership that takes initiative to ensure the implementation of empowering processes in group activities is entirely consistent with group members' empowerment; the analytic separation required of leadership to attend to this implementation assists in forming cohesion and group authority.

PROPOSITION 2B. In women's groups based on feminist principles and aimed at being empowering, the more leaders carry out leadership that is simultaneously facilitative and initiating, the more empowering the group will be for its members.

To paraphrase one of the lines in Barbara's poem (Figure 1), "No one said that holding tensions is easy." It is almost certain to create ambivalence in leaders and members, as was the case in the NFDC. Leaders may be keenly aware of their separateness from the group, for good and for bad. Initiating leaders may experience that as they foster the group's empowerment agenda they are simultaneously enhancing their own power. They may simultaneously enjoy and feel guilty about the power associated with their position. Members may be keenly aware that they are allowing the leaders to take initiative. As a result, they may also feel their own status and 
contribution devalued (Gemmill and Oakley 1992) especially given an empowerment agenda. Facultative leaders may experience less power, perhaps less than they would like.

PROPOSITION 3A. The more leaders of women's groups based on feminist principles aim at fostering empowerment among group members, the more likely the group will experience ambivalence surrounding leadership.

Despite the difficulties experienced in holding ambivalence and conflict, ambivalent feelings and internal conflicts may be necessary components of attempts to create empowering groups, not only among women, but in many organizational change efforts (Gilmore et al. 1997). To the degree that leaders articulate and address such feelings and conflicts within themselves, they are likely to surface similar conflicts within other members and within the larger group. Giving voice to this ambivalence, making it conscious in the group, can help members surface implicit assumptions about empowerment and leadership, and, perhaps, help them learn to expect the ambivalence as appropriate. This realization can help them sustain the ambivalence:

PROPOSITION 3B. In women's groups designed based on feminist principles that aim at being empowering, the more ambivalence surrounding authority is articulated as appropriate, the better the group members can sustain the ambivalence and contradictions in the group.

\section{$\underline{\text { Conclusion }}$}

Using a longitudinal qualitative database, one of the few of its kind, we have examined leadership in an empowering women's group over several years and several leadership successions. Our analyses showed the group's willingness to experiment with a style of leadership that the members saw as reflecting their values. These analyses also indicated that leadership aimed at being empowering in such a group invokes dilemmas, tension, and ambivalence. Attempts to resolve dilemmas in the group we studied appeared over time to have had the unintended effect of reducing the capacity of the group to take internal initiative.

We suggested above that while our study focuses on the specific issues of leadership within a group aimed at empowering women, it also has implications for broader issues of dilemmas and contradictions in organizational behavior and change. Our findings are consistent with the idea that tensions and ambiguity are necessary components of situations that involve dilemmas and contradiction in some ways (Quinn and Cameron 1988). Moreover, it seems likely that most significant organizational change attempts will involve such dilemmas and contradictions (Gilmore et al. 1997). Our data show how attempts to deal with these evolve over the course of a maturing group; they indicate that even though attempts are made to be reflective and reflexive (Hatch 1997), it is difficult to maintain a kind of healthy tension that accompanies both sides of contradictions.

We have proposed that a useful next step in learning to deal with such contradictions is to articulate them and to express the value of contradictions in themselves. True exploration of the usefulness of this proposal awaits another group, perhaps one similar to the NFDC, that has the creativity and courage over time to try to express its cherished values in its practices and to articulate the contradictions that arise in conjunction with this expression. 


\section{ACKNOWLEDGMENTS}

The authors thank Joyce Fletcher, Erica Foldy, Kathy Kram, and three anonymous reviewers for their very insightful comments on earlier drafts of this paper. They also thank Susan Eaton, Judith Jordan, Jean Baker Miller, Christina Robb, and Maureen Walker for helpful conversation about core ideas in the paper. An earlier version of this paper was presented at the Academy of Management meeting, Boston 1997. 
Table 1. Year, NFDC Membership, Work, and Summary of Leader Succession Processes and Metaphors.

\begin{tabular}{|c|c|c|c|c|}
\hline Years & Mombers & $\begin{array}{c}\text { Focus of NFDC Work } \\
\text { During Year(s) }\end{array}$ & $\begin{array}{c}\text { Events During Leadership } \\
\text { Succession Process }\end{array}$ & $\begin{array}{l}\text { Images and Metaphors } \\
\text { Used During Leadership } \\
\text { Succession Process }\end{array}$ \\
\hline \multicolumn{5}{|c|}{ Founders: Catherine and Diane } \\
\hline $1988-1950$ & $\begin{array}{l}\text { Catherine-coleader } \\
\text { Diane-coleader } \\
\text { Joan } \\
\text { Barbara } \\
\text { Inga } \\
\text { Marion } \\
\text { Marie } \\
\text { (Diane, Marion, and } \\
\text { Inga rotate off the } \\
\text { committee. Evelyn, } \\
\text { Doris, and Colleen } \\
\text { join.) }\end{array}$ & $\begin{array}{l}\text { - Sell-organization } \\
\text { - Initiating NuE } \\
\text { - First Faculty Institule } \\
\text { - Founders enact } \\
\text { collaborative style }\end{array}$ & $\begin{array}{l}\text { - Diane decides to rocate off } \\
\text { the committee, not just ofl } \\
\text { leadership. } \\
\text { - Group docides, after a long } \\
\text { and difficult discussion, to } \\
\text { maintain coleaders. } \\
\text { - Members hesitate to } \\
\text { assume leadership; } \\
\text { eventually Joan and } \\
\text { Barbara volunseer }\end{array}$ & $\begin{array}{l}\text { - A pobential successor had } \\
\text { to decicle if she had "what it } \\
\text { took" to follow tounders' } \\
\text { leadership model. (3)" } \\
\text { - A successor described "a } \\
\text { child who neods the parents } \\
\text { to (take leadorship)" (6) } \\
\text { - In a later moeting a } \\
\text { successor described the } \\
\text { founders as "Pathfinders. } \\
\text { Netcasters, Firebringers, } \\
\text { and Torchbearers" (Fig. } \\
\text { ure 1) }\end{array}$ \\
\hline $1990-1991$ & $\begin{array}{l}\text { Joan-coleader } \\
\text { Barbara-coleacber } \\
\text { Catherine } \\
\text { Marie } \\
\text { Evelyn } \\
\text { Doris } \\
\text { Colloen } \\
\text { (Barbara, Evelyn, and } \\
\text { Marie rotate ott the } \\
\text { commintee. Sara, Meg. } \\
\text { and Jackie join.) }\end{array}$ & $\begin{array}{l}\text { - NFDC members worked to } \\
\text { plan the second Faculty } \\
\text { Institute and to publish the } \\
\text { neot volume of the NJE. } \\
\text { - NFDC conducted an alchol } \\
\text { intervention } \\
\text { - Barbara and Joan } \\
\text { continued the founders' } \\
\text { leadership style. Thery } \\
\text { became aware of } \\
\text { paradoxes associated with } \\
\text { that style. }\end{array}$ & $\begin{array}{l}\text { - Members questioned } \\
\text { whether the leadership style } \\
\text { inherited from the founders } \\
\text { truly was fully collaborative } \\
\text { - Members redesigned } \\
\text { leadership to be shared and } \\
\text { rotated among group } \\
\text { members. A coordinator } \\
\text { would work with the Network } \\
\text { oflice but have no special } \\
\text { authority within the NFrDC. } \\
\text { Joan remains as } \\
\text { coordinator. }\end{array}$ & $\begin{array}{l}\text { - A leader identifies a } \\
\text { "mystique of leadership" (9) } \\
\text { - Leaders have a "special } \\
\text { collaboration" (10) } \\
\text { - There is a "power } \\
\text { imbalance" (10) } \\
\text { - "Ownership" (12) vs. } \\
\text { "Queen of the Universe" } \\
\text { (10) } \\
\text { - New leadership plan fosters } \\
\text { "sharing the burden," } \\
\text { "sharing the anvoicty" (12) }\end{array}$ \\
\hline $1991-1992$ & $\begin{array}{l}\text { Joan-coordinator } \\
\text { Colloen } \\
\text { Catherine } \\
\text { Doris } \\
\text { Sara } \\
\text { Mog } \\
\text { Jackie } \\
\text { (Joan rotates oft the } \\
\text { committee. Dana } \\
\text { joins.) }\end{array}$ & $\begin{array}{l}\text { - Group members initiate new } \\
\text { leadership plan } \\
\text { - Thery work on developing } \\
\text { the proposals submitted at } \\
\text { the prior Faculty } \\
\text { Development instinute to } \\
\text { submit for grants }\end{array}$ & $\begin{array}{l}\text { - Discussion of leadership } \\
\text { succession is more } \\
\text { pragnatic and shorter than } \\
\text { price years } \\
\text { - Colloen is nominatod as } \\
\text { coorcinator and accepts }\end{array}$ & $\begin{array}{l}\text { - The coordinator no longer } \\
\text { has "queenly qualities." } \\
\text { Instead, she can "play } \\
\text { dumb" and count on her } \\
\text { friends to "pick her up" } \\
\text { should she fall down (13) }\end{array}$ \\
\hline 1992-1993 & $\begin{array}{l}\text { Colleen-coctdinator } \\
\text { Sara } \\
\text { Catherine } \\
\text { Doris } \\
\text { Meg } \\
\text { Dana } \\
\text { dackie } \\
\text { (Colleen, Doris, and } \\
\text { dackie rotate ot the } \\
\text { committee. Bonnie, }\end{array}$ & $\begin{array}{l}\text { - Planning for the third } \\
\text { Instituse, which would } \\
\text { include both taculty and } \\
\text { administrators } \\
\text { - NFDC meets with } \\
\text { administrative group and } \\
\text { works to improve its } \\
\text { external communication } \\
\text { - Colleen develops a manual }\end{array}$ & $\begin{array}{l}\text { - Conversation about } \\
\text { leadership succession is } \\
\text { brief } \\
\text { - Sara is nominated as next } \\
\text { coordinator and accepts }\end{array}$ & $\begin{array}{l}\text { - The group is "woaned" fecm } \\
\text { "the coordinator being the } \\
\text { queen" (14) } \\
\text { - "Communify of this table" is } \\
\text { "united" (15, 16) } \\
\text { - The new coordinalor is } \\
\text { "scared to death," but } \\
\text { stands on firm ground for } \\
\text { this "new step" (16) }\end{array}$ \\
\hline
\end{tabular}




\begin{tabular}{|c|c|c|c|c|}
\hline Years & Members & $\begin{array}{l}\text { Focus of NFDC Work } \\
\text { During Year(s) }\end{array}$ & $\begin{array}{l}\text { Events During Leadership } \\
\text { Succession Process }\end{array}$ & $\begin{array}{l}\text { Images and Metaphors } \\
\text { Used During Leadership } \\
\text { Succession Process }\end{array}$ \\
\hline 1993-1994 & $\begin{array}{l}\text { Sara-coordinator } \\
\text { Dana } \\
\text { Catherine } \\
\text { Meg } \\
\text { Bonnie } \\
\text { Jana } \\
\text { Monica }\end{array}$ & $\begin{array}{l}\text { - NFDC members worked to } \\
\text { develop proposals based } \\
\text { on recommendations of } \\
\text { prior institutes. They also } \\
\text { worked on computer links } \\
\text { across schools. Evaluation } \\
\text { of their impact was } \\
\text { assessed. }\end{array}$ & $\begin{array}{l}\text { - First person nominated } \\
\text { (Meg) to be coordinator } \\
\text { does not want to accept the } \\
\text { position. Next person } \\
\text { nominated (Sara) accepts } \\
\text { after brief discussion. }\end{array}$ & $\begin{array}{l}\text { - NFDC accepts first } \\
\text { nominee's assessment that } \\
\text { she can exercise "astute" } \\
\text { leadership better internally. } \\
\text { Group chooses a leader } \\
\text { who will know when to } \\
\text { "wail" for its needs to the } \\
\text { Network director. (17) }\end{array}$ \\
\hline & & & & $\begin{array}{l}\text { - "The Queen is dead; long } \\
\text { live the queen" (17) }\end{array}$ \\
\hline
\end{tabular}


Figure 1. Poem Written About the Founders of the NFDC by One of the First Successors in Leadership.

\section{TEACHERS}

1. Pathfinders

First you found a way into the cloudy forest, saw fireflies dancing where others snatched at gnatsglimmers of light along a rocky cliff edgerolled will-o'-the wisps into luminous lanterns shining beyond boulders and fallen trees, to discover the path itself is a destination.

2. Netcasters

Your journey made no sense unless the way could be traveled by others at your side.

Knowing the delicacy of fishing for equals, with patience and care you cast the nets in circles always wider and wider, loving the prey, swimming beside us, to prove the net is not a snare but a doorway.

\section{Firebringers}

The true audacity is people bringing fire to people, gathered slowly, spark by spark, laborious, treacherous sometimes, flashing back to sear youNo one said being Prometheus was easy.

4. Torchbearers

Holding your torches high, you let the light shine over the way where the rest can join you. Clearer now we see where the path may lead, not yet the place achieved, but, with you, knowing the pains of the trail make it wider and surer; that rocks piled high enough can become a lookout; of branches that block the way, we can build bridges. . . . 


\section{REFERENCES}

1. Alexander, J. A., M. L. Fennell, M. T. Halpern. 1993. Leadership in stability in hospitals: The influence of board-CEO relations and organizational growth and decline. Admin. Sci. Quart. 38 74-99.

2. Bartunek, J. M., P. Foster-Fishman, C. B. Keys. 1996. Using collaborative advocacy to foster intergroup cooperation: A joint insider-outsider investigation. Human Relations. 49 701-733.

3. D. Greenberg, B. Davidson. 1999. Consistent and inconsistent impacts of a teacherled empowerment initiative in a federation of schools. J. Appl. Behavioral Sci. 35 457-478.

4. C. A. Lacey. 1998. The roles of narrative in understanding work group dynamics associated with a dramatic event: Confronting alcoholism, J. A. Wagner, III, ed. Advances in Qualitative Res. Vol. 1. JAI Press, Greenwich, CT. 33-66.

5. __ D. R. Wood. 1992. Social cognition in organizational change: An insideroutsider approach. J. Appl. Behavioral Sci. 28 204-223.

6. CA. , M. R. Louis. 1996. Insider/outsider team research. Sage Publications, Thousand Oaks,

7. Bass, B. M. 1985. Leadership and performance beyond expectations. Free Press, New York.

8. Berg, D. N. 1990. Reflections on the development of a supervisor. J. Gillette, M. McCollom, eds. Groups in context. Addison-Wesley Publishing Co., Inc., Reading, MA. 318-336.

9. Brink, T. L. 1993. Metaphor as data in the study of organizations. J. Management Inquiry. 2 366-371.

10. Burns, J. M. 1978. Leadership. Harper \& Row, New York.

11. Cameron, K., D. Whetten. 1983. Models of organizational life cycle: Applications to higher education. Rev. Higher Ed. 6 269-299.

12. Chen, C. C., J. R. Meindl. 1991. The construction of leadership images in the popular press: The case of Donald Burr and People Express. Admin. Sci. Quart. 36 521-551.

13. Conger, J. A. 1989. Leadership: The art of empowering others. Acad. Management Executive 3 17-24.

14. Correa, M. E., E. B. Klein, W. N. Stone, J. H. Astrachan, E. E. Kossek, M. Komarraju. 1988. Reactions to women in authority: The impact of gender on learning in group relations conferences. J. Appl. Behavioral Sci. 24 219-234.

15. Denmark, F. L. 1994. Women, leadership, and empowerment. Psych, of Women Quart. 17 343-356. 
16. Eagly, A. H., S. J. Karau, B. T. Johnson. 1992. Gender and leadership style among school principles: A meta-analysis. Ed. Admin. Quart. 28 76-102.

17. M. G. Makhijani. 1995. Gender and the effectiveness of leaders: A metaanalysis. Psych. Bull. 117 125-145.

18. _ B. T. Johnson. 1990. Gender and leadership style: A meta-analysis. Psych. Bull. 108 233-256.

19. __ M. G. Makhijani, B. G. Klonsky. 1992. Gender and the evaluation of leaders: A metaanalysis. Psych. Bull. 111 3-22.

20. Fletcher, J. K. 1999. Disappearing Acts: Gender, Power, and Relational Practice at Work. MIT Press, Cambridge, MA.

21. Gastil, J. 1994. A definition and illustration of democratic leadership. Human Relations $47953-$ 975.

22. Gemmill, G., J. Oakley. 1992. Leadership: An alienating social myth? Human Relations. 45 113-129.

23. Gephart, R. P. 1978. Status degradation and organizational succession: An ethnomethodological approach. Admin. Sci. Quart. 23 553-581.

24. Gilligan, C. 1982. In a Different Voice: Psychological Theory and Women's Development. Harvard University Press, Cambridge, MA.

25. Gilmore, T. N., G. P. Shea, M. Useem. 1997. Side effects of corporate cultural transformations. J. Appl. Behavioral Sci. 33 174-189.

26. Goodstein, J., W. Boeker. 1991. Turbulence at the top: A new perspective on governance structure changes and strategic change. Acad. Management J. 34 306-330.

27. Gordon, G. E., N. Rosen. 1981. Critical factors in leadership succession. Organ. Behavior and Human Performance. 27 227-254.

28. Hackman, J. R., R. E. Wallon. 1986. Leading groups in organizations, P. S. Goodman and Associates, eds. Designing Effective Work Groups. Jossey-Bass, San Francisco, CA. 79-119.

29. Handy, C. 1994. The Age of Paradox. Harvard Business School Press, Boston, MA.

30. Hatch, M. J. 1997. Irony and the social construction of contradiction in the humor of a management team. Organ. Sci.. 8 275-288.

31. Hegelsen, S. 1990. The Female Advantage: Women's Ways of Leadership. Doubleday Currency, New York.

32. Heller, T. 1989. Conversion processes in leadership succession: A case study. J. Appl. Behavioral Sci. 25 65-77. 
33. Hersey, P. H., K. H. Blanchard. 1988. Management of Organizational Behavior: Utilizing Human Resources, 5th ed. Prentice-Hall, Englewood Cliffs, NJ.

34. House, R. J. 1977. A 1976 theory of charismatic leadership. J. G. H. Larson, L. L. Larson, eds. Leadership: Cutting Edge. Southern Illinois University Press, Carbondale, IL.

35. Jago, A. G., V. H. Vroom. 1982. Sex differences in the incidence and evaluation of participative leader behaviors. J. Appl. Psych. 67 776-783.

36. Johnson, V. E. 1980. I'Il Quit Tomorrow. Harper \& Row, San Francisco, CA.

37. Jordan, J. V. 1997. The relational model is a source of empowerment for women. M. R. Walsh, ed. Women, Men and Gender: Ongoing Debates. Yale University Press, New Haven, CT.

38. Jordan, J. V., A. Kaplan, J. B. Miller, I. Stiver, J. Surrey, J. 1991. Women's Growth in Connection. The Guilford Press, New York.

39. Kesner, I. F., D. R. Dalton. 1994. Top management turnover and CEO succession: An investigation of the effects of turnover on performance. J. Management Stud. 31 701-713.

40. _ T. C. Sabora. 1994. Executive succession: Past, present and future. J. Management. $20327-372$.

41. Klenke, K. 1996. Women and Leadership: A Contextual Perspective. Springer, New York.

42. Kram, K. E., M. M. Hampton. 1998. When women lead: The visibility-vulnerability spiral. E. G. Klein, F. Gabelnick, P. Herr, eds. The Psychodynamics of Leadership. Psychosocial Press, Madison, CT.

43. Kraus, G., G. Gemmill. 1990. Idiosyncratic effects of implicit theories of leadership. Psych. Reports, 66 247-257.

44. Lacey, C., D. Wood, J. M. Bartunek. 1990. A committee of teachers for teachers: The first year. Convention talk. Amer. Ed. Res. Assoc. Boston, MA.

45. Lakoff, G., M. Johnson. 1980. Metaphors We Live By. University of Chicago Press, Chicago, IL.

46. Lies, B. B. 1993. The Poet's Pen: Writing Poetry with Middle and High School Students. Teachers Ideas Press, Englewood, CO.

47. Loden, M. 1985. Feminine Leadership or How to Succeed in Business Without Being One of the Boys. Random House, Toronto, Canada.

48. Louis, M. L., R. I. Sutton. 1991. Switching cognitive gears: From habits of mind to active thinking. Human Relations. 44 55-76.

49. Lundberg, C. 1986. The dynamic organizational contexts of executive succession: Considerations and challenges. Human Resource Management 25 287-303. 
50. Manz, C. C. 1990. Beyond self managing work teams: Toward self-leading teams in the workplace. W. A. Pasmore, R. W. Woodman, eds. Research In Organizational Change and Development. JAI Press, Greenwich, CT. 273-299.

51. Manz, C. C., H. P. Sims, Jr. 1980. Self management as a substitute for leadership: A social learning theory perspective. Acad. of Management Rev. 5 361-367.

52. ___ 1984. Searching for the 'unleader,' Organ, member views on leading selfmanaged groups. Human Relations 37 409-424.

53. ___ 1987. Leading workers to lead themselves: The external leadership of self managing work team. Admin. Sci. Quart. 32 106-128.

54. Miller, J. B. 1976. Toward a New Psychology of Women. Beacon Press, Boston, MA.

55. Miller, D. 1993. Some organizational consequences of CEO succession. Acad. Management J. 36 644-659.

56. Moch, M. K., J. M. Bartunek. 1990. Creative Alternative Realities at Work: The Quality of Worklife Experiment at FoodCom. Harper Business, New York.

57. _ W. C. Fields. 1985. Developing a content analysis for interpreting language use in organizations. S. Mitchell, S. Bacharach, eds. Research in the Sociology of Organizations, Vol. 4, JAI Press, Greenwich, CT. 81-126.

58. Muller, H., C. Cocotas. 1988. Women in power: New leadership in the health industry. Health Care for Women Internat. 9 63-82.

59. Neuse, S. 1978. Professionalism and authority: Women in public service. Public Admin. Rev. 38 36-41.

60. Palmer, I., R. Dunford. 1996. Conflicting uses of metaphors: Reconceptualizing their use in the field of organizational change. Acad. Management Rev. 21 691-717.

61. Pfeffer, J., A. Davis-Blake. 1986. Administrative succession and organizational performance: How administrator experience mediates the succession effect. Acad. Management J. 29 7283.

62. Quinn, R. E., D. Anderson. 1984. Formalization as crisis: Transition planning for a young organization. J. Kimberly, R. Quinn, eds. Managing Organizational Transitions. Irwin, Homewood, IL, 11-28.

63. __ K. S. Cameron. 1983. Organizational life cycles and the criteria of effectiveness. Management Sci. 29 33-51.

64. ___ 1988. Paradox and Transformation: Toward a Theory of Change in Organ, and Management. Ballinger, Cambridge, MA.

65. Riger, S. 1994. Challenges of success: Stages of growth in feminist organizations. Feminist Studies. 20 275-300. 
66. Rosener, J. 1990. Ways women lead. Harvard Bus. Rev. 68 119-125.

67. Sackmann, S. 1989. The role of metaphors in organization transformation. Human Relations. 42 463-485.

68. Sims, H., P. Lorenzi. 1992. The New Leadership Paradigm, Social Learning and Cognition in Organizations. Sage Publications, Inc., Newbury Park, CA.

69. Smith, K. K., D. N. Berg. 1987. Paradoxes of Group Life. Jossey-Bass, San Francisco, CA.

70. Smith, M., M. C. White. 1987. Strategy, CEO specialization and succession. Admin. Sci. Quart. 32 263-280.

71. Srivastva, S., F. J. Barrett. 1988. The transforming nature of metaphors in group development: A study in group theory. Human Relations. 4131-64.

72. Stewart, G. L., C. C. Manz. 1995. Leadership for self-managing work teams: A typology and integrative model. Human Relations. 48 747-770.

73. Tichy, N. M., D. O. Ulrich. 1984. The leadership challenge: A call for the transformational leader. Sloan Management Rev. 26 59-68.

74. Valentine, P. 1995. Women's working worlds: A case study of afemale organization. D. M. Dunlap, P. A. Schmuck, eds. Women Leading in Edu. State University of New York Press, Albany, NY. 340-357.

75. Virany, B., M. L. Tushman, E. Romanelli. 1992. Executive succession and organizational outcomes in turbulent environments: An organizational learning approach. Organ. Sci. 3 7291.

76. Vroom, V. H., A. C. Jago. 1995. Situation effects and levels of analysis in the study of leader participation. Leadership Quart. 6 169-181.

77. Yukl, G. 1998. Leadership in Organizations, 4th ed. Prentice-Hall, Englewood Cliffs, NJ. 